Lessons of peace in Aceh: administrative decentralization and political freedom as a strategy of pacification in Aceh

Javier Gil Pérez

INSTITUT

CATALÀ

INTERNACIONAL

PER LA PAU 


\section{Lessons of peace in Aceh: administrative decentralization and political freedom as a strategy of pacification in Aceh}

Javier Gil Pérez

Researcher in the University Institute General Gutiérrez Mellado

He has been a research associate in the Rajaratnan School of International Studies in Singapore and also visiting fellow in the Center of Strategic and International Studies of Jakarta. His areas of work are: political Islam, terrorism, new threats to security in Southeast Asia and international relations between Asia and the Middle East.

javier_gil20o1@yahoo.com

Text comissioned by the Institut Català Internacional per la Pau.

Institut Català Internacional per la Pau

Barcelona, desembre 2009 
(C) 2009 Institut Català Internacional per la Pau

Gran Via, 658, baix. 08010 Barcelona

T. +34935544270 | F. +34935544280

recerca.icip@gencat.cat | www.icip.cat

\section{Editorial Board}

Javier Alcalde and Rafael Grasa

\section{Consell Editorial}

Pablo Aguiar, Alfons Barceló, Catherine Charett, Gema Collantes, Caterina Garcia, Abel Escribà, Vicenç Fisas, Tica Font, Antoni Pigrau, Xavier Pons, Alejandro Pozo, Mònica Sabata, Jaume Saura, Antoni

Segura and Josep Maria Terricabras

\section{Traslation}

Luke Moreland

Typesething

Ātona, S. L.

\section{Graphic Designer}

Cla-se

\section{ISSN}

2013.5793 (edición en línea)

2013.5785 (edición en papel)

DL

B-38.039-2009

\section{All rigths reserved}




\section{ABSTRACT (ENG)}

This working paper shows the evolution of the Aceh conflict until its peaceful resolution in 2005. The key factors in the success of this peace process have been the confluence of several factors related to the internal and external dynamics of the country, including the new political leadership, the decreasing role of the military power, the international support and the meeting of the objectives of both groups, and so on. The end of the conflict in Aceh shows that the administrative decentralization and the promotion of the political participation of the main actors involved have made possible the development of a solid alternative to the arms strategy of conflict resolution used for years in Indonesia.

Key words: Aceh, Aceh Monitoring Mission, Susilo Bambang, GAM, Memorandum of Understanding.

\section{ABSTRACT (CAT):}

Aquest document de treball mostra l'evolució del conflicte a Aceh fins a la seva resolució pacífica el 2005. Les claus de l'èxit d'aquest procés de pau han estat la confluència de diversos factors lligats a les dinàmiques interna $i$ externa del país: nou lideratge polític, pèrdua del rol per part dels militars, recolzament internacional i acomodació dels objectius de les dues parts, etc. La resolució del conflicte a Aceh posa de manifest com la descentralització administrativa i el foment de la participació política dels principals actors involucrats han permès desenvolupar una alternativa sòlida a l'estratègia armada de resolució de conflictes utilitzada durant diversos anys a Indonèsia.

Paraules clau: Aceh, Missió de Supervisió d'Aceh, Susilo Bambang, GAM, Memoràndum d'Entesa 


\section{ABSTRACT (CAS):}

El presente documento de trabajo muestra la evolución del conflicto en Aceh hasta su resolución pacífica en 2005. Las claves del éxito de este proceso de paz han sido la confluencia de varios factores ligados a las dinámicas interna y externa del país: nuevo liderazgo político, pérdida del rol por parte de los militares, apoyo internacional y acomodación de los objetivos de ambos bandos, etc. La resolución del conflicto en Aceh pone de manifiesto como la descentralización administrativa y el fomento de la participación política de los principales actores involucrados han permitido desarrollar una alternativa sólida a la estrategia armada de resolución de conflictos utilizada durante años en Indonesia.

Palabras clave: Aceh, Misión de Supervisión de Aceh, Susilo Bambang, GAM, Memorando de Entendimiento. 


\section{CONTENTS:}

ACRONYMS

1. INTRODUCTION

1.1 PRESENTATION OF CONFLICT

1.2 THE ROLE OF ISLAM IN INDONESIA

1.3 ACEH, SUHARTO AND THE PERIOD OF REFORM

2. FIRST PEACE PROCESS

2.1 CAUSES OF FAILURE

3. SECOND PEACE PROCESS

3.1 ESTABLISHMENT OF THE MEMORANDUM OF UNDERSTANDING

4. DEVELOPMENT OF THE LAW ON THE GOVERNING OF ACEH-LOGA

5. PROBLEMS

6. CONCLUSIONS

7. REFERENCES 



\section{ACRONYMS}

AMM: Aceh Monitoring Mission

ASEAN: Association of Southeast Asian Nations

BPUPKI: Badan Penyelidik Usaha Persiapan Kemerdekaan IndonesiaCommittee for the Preparation of Independence of Indonesia

CMI: Crisis Management Initiative

COHA: Cessation of Hostilities Framework Agreement

DI: Darul Islam-House of Islam

DOM: Daerah Operasi Militer- District of Military Operations

FAS: Armed Forces

GAM: Gerakan Aceh Merdeka-Free Aceh Movement

GoI: Government of Indonesia

HDC: Henry Dunant Center

IMP: Initial Monitoring Presence

JCHA: Joint Committee for Humanitarian Action

JCSM: Joint Committee for Security Modalities

LOGA: Law on Governing of Aceh

MoU: Memorandum of Understanding

MPR: Majelis Permusyawaratan Rakyat-Consultative Advisory of the People

PA: Party of Aceh

PD: Democratic Party

PERDA: Peraturan Daerah-District Regulation

PKI: Partai Komunis Indonesia- Communist Party of Indonesia

SBY: Susilo Bambang Yudhoyono

TNI: Tentara Nasional Indonesia-National Army of Indonesia

EU: European Union 



\section{INTRODUCTION}

The peace process was finally realized in 2005 between the Gerakan Aceh Merdeka-Free Aceh Movement ${ }^{1}$ (GAM) and the Government of Indonesia (GoI) putting an end to more than 130 years of conflict and marking an extremely positive milestone in conflict management. This case is not only important for southeast Asia but also establishes a good model for future processes of peace that can be carried out in other areas of Asia, such as the cases of Mindanao in the Philippines or Xinjian in China, as well as for conflicts in other parts of the world. After four years of the signing of the peace agreement and the celebration of several local and national elections in the region, the peace is gradually becoming a reality demonstrating that the foundations of peace are solid.

The objective of this working document is to analyze what are these foundations and to explicate the principal points of the process that brought peace to the most western region of Indonesia, Aceh. The key is to show how the political decentralization of Indonesia that started after the beginning of the democratic period in 1999 together with the loss of the Eastern province of East Timor the same year encouraged a political agreement between GAM and the Government of Indonesia. In addition to several other factors this political agreement was definitive in endowing great political and economic power to Aceh within Indonesia. As this paper shows, the agreement could not have been made in a non democratic period and without the existence of the two internal dynamics mentioned before. It is because of that that the peace agreement signed in 2005 not only has to be analyzed from the perspective of the peace process itself, but also, and this is vital, from the internal dynamic of the country that opened possibilities and allowed the entry of ideas that before had always remained closed by Suharto.

1. To know more about GAM consult «What is the Free Aceh Movement?» at http:// insideindonesia.org/digest/dig89.htm 
Another key point that will be studied in this working document will be the importance of international influence in the resolution of this conflict. This international influence refers to two crucial events. First, the work done by the Crisis Management Initiative (CMI) headed by the former first minister of Finland, Martti Ahtisaari, who pushed for the negotiations of peace after the frustration caused by the breach of the first peace process led by the Henry Dunant Center. Second, and perhaps of greater importance for the process of consolidating peace has been the creation of the Aceh Monitoring Mission (AMM). The participation of the AMM warrants an intensive investigation because it led to two efforts of vital importance: first, the mission of the AMM has been the first great example of cooperation in maintaining peace and security among the EU and ASEAN; second, the development of the AMM turned into the first experience of the EU in Asia paving the way for future operations of peace of the EU in Asia. Three possible future undertakings include: first, the conflict in the south of the Philippines, second, the war in the Muslim area in the south of Thailand, and third, the increasing tension in Papua.

To analyze this conflict and its subsequent solution, the working document is divided up into five parts: 1) an introduction to the conflict that will show what have been the main causes that have allowed the conflict to persist during the occupation of the Dutch, Japanese and the years of Sukarno and Suharto, 2) the causes of the failure of the first peace process that at the same time provided lessons of conflict resolution to follow later, 3) the reasons for the success of the second peace process centred on the final accommodation between the State of Indonesia and the region of Aceh, 4) a detailed explanation of the benefits of that agreement represented in the Law on the Governing of Aceh (LOGA), which gives formal structure to peace in the region and goes far to sustain it, and finally 5) a series of problems are explained concerning what is happening with the application of the LOGA in Indonesia. One of these problems is the difficulty of the introduction of Islamic Sharia in Aceh that is causing a new problem in the country such as the severe discrepancies that it causes in legal matters. An example is the last law approved by the assembly of Aceh that supports the 
stoning of prostitutes, drinkers of alcohol, those who have sex without being married, and other perceived infractions, laws that have caused controversy in a wide sector of the country. Finally, the main conclusions of this working document will intend to shed light on one of the greatest successes in terms of seeking solutions to conflicts that have occurred in recent years. All of these aims are founded on the hope for peaceful solutions and dialogue to put an end to violence. Peace itself deserves an effort on the part of everyone.

\subsection{PRESENTATION OF THE CONFLICT}

Aceh is the most western region of Indonesia ${ }^{2}$ situated in the western end of the island of Sumatra and is known in Indonesia for three aspects. First, it is one of the main economic powers of Indonesia with its important reserves of minerals, timber, oil, gas and marine resources. Second, Aceh is also called the Veranda of Mecca $^{3}$ where a more conservative and more rigorous Islam is practiced. This characteristic is related with the myth that the first point of entry of Islam in the Indonesian archipelago was in Aceh with the arrival of the first Arab traders and Indians of Gujarat. At the same time and for centuries, Aceh was the preliminary port of the pilgrims towards Mecca in their boat trip up to the religious centre of Islam. These facts make the province of Aceh one of the places of Indonesia with deeper religiousness among the population and this religious history has a profound influence on all aspects of contemporary life. A third important feature is that in Aceh like in other regions of Indonesia there is one important nationalistic identity tied up with the language of the region, the local culture and an important inheritance of traditions originating in the local history of Aceh. For centuries that history was rooted in an independent sultanate that only

2. Consult the web page of the government of Aceh to obtain more information about the region. http://www.nad.go.id/

3. SOETJIPTO Tomi Soetjipto «Aceh's Mecca pilgrims find homes washed away» at http:// www.theage.com.au/news/asia-tsunami/acehs-mecca-pilgrims-find-homes-washed-

away/2005/01/28/1106850105912.html 
came to an end when invaded by Holland in $1873^{4}$. Since that precise instant up to the present, Aceh stopped being a free sultanate to become incorporated by Holland first, later to the Japanese empire in 1942 after the defeat of Holland to the Japanese during World War II and later by the new Republic of Indonesia in 1945. Thus, Aceh is a region that after the end of the decolonizing process in 1945 has not recovered its old status of sultanate lost 140 years ago.

These three variables, economics, religion and nationalism have marked the historical evolution of Aceh in its relationship with the two colonial powers that dominated Indonesia: Holland from the 18th century up to 1942, Japan from 1942 to 1945 and then Indonesia itself from the beginning of the independent stage of the country in 1945 up to the signing of the peace agreement in 2005 .

Inside the conflict of Aceh with the central power of the period a series of critical dates mark the evolution of the historical conflict.

First, Aceh was an independent sultanate up to its conquest by the Dutch colonial forces in 1873. It is necessary to explain several points about this important year. First, it was in 1873 when the Dutch troops in their desire for controlling the whole of Indonesia and above all Aceh as a commercial and strategic base, started to deploy and spread throughout the region. This situation escalated in 1873 into the start of the Aceh War that finished in 1904 with the conquest of Aceh. This war was a terrible and bloody fight between the Dutch troops and the guerrillas of Aceh. Holland needed 30 years finally to bend the resistance in Aceh and to control them with security. Contrary to the opinions of historians, in the imagination of the secessionist movement of Aceh it has always been defended that Aceh never was under total Dutch control.

This war left a double legacy in the area of Aceh. It created a deep hatred for the invader and it left an important inheritance for future secessionist movements in Aceh. This history is important because it is one of the

4. LINGA Abhoud Syed M. «Aceh peace process: A Lessons for Mindanao« at http://library. upmin.edu.ph/philmin/bangsamoro/IBS\%20Occasional\%20Paper\%202007-03\%20-\%20 Lingga.pdf 
reasons for the durability and the aggressiveness of the conflict when it reemerged during the stage of Suharto.

\subsection{THE ROLE OF ISLAM IN INDONESIA}

Once the sultanate was controlled by the Dutch jurisdiction, Aceh always experienced a situation of instability with continuous ups and downs that marked its relationship with the central power of the period. There are three historical periods that have to be considered in the evolution of the conflict:

1) during the stage of Sukarno from 1945 to 1965.

2) During the stage of Suharto from 1965 to 1998.

3) First legislature of the democratic stage of Indonesia with Abduraman Wahid ${ }^{5}$ «Gus Dur» and Megawati Sukarnoputri.

Sukarno like Suharto was an adamant nationalist. This aspect is important because it would influence all the relations of Aceh with the political centre of the country, Jakarta. Sukarno estimated that to maintain the unity of the country it was necessary to maintain two policies. First, there would not be only one official religion of the State as the Islamist group claimed with regard to situating Islam as the constitutional base of the new country. Second, to avoid separatist tensions it was necessary not to open the decentralizing process. This might have led towards independence for some of the regions of Indonesia for ethnic and cultural reasons along with other factors that made these regions reticent to embrace the new Republic of Indonesia. Some of these regions were Aceh, Maluku and Papua. Because of these tensions, during the 20 years of mandate of Sukarno these two policies were maintained stringently.

5. More information about Gus Dur at http://www.tokohindonesia.com/ensiklopedi/a/ abdurrahman-wahid/index.shtml 
The subject of the role of Islam in Indonesia was very important especially during the years prior to the declaration of independence of the Republic of Indonesia in 1945. During this time intellectuals of the country led a lively debate in the country on what should be the legal base of the future Indonesian State. Two groups clearly emerged with delimited agendas, defined objectives and stood counter opposed. On one side there was a nationalistic group led by Sukarno. On the other was an Islamist group led by Mohamed Natsir. Aceh was one of the main regions that defended the Islamic State. It is important to revisit this debate as it reflects Acehnese ideas on the role of religion in the State and contextualizes their desires for the introduction of the Sharia into the judicial order of Aceh.

The division of the Muslim community between these two sides of the debate is due to the different appreciation of the role that both groups have given to Islam in the political life of the country. These two groups responded to the same divisions that exist today in the Indonesian Muslim community between the formalistic and substantial visions ${ }^{6}$. The first set of ideas for Efendi is about «those that try to use the Sharia as the primary source of law. This implies that the protection of Human Rights, the mechanisms of balance and control of power, independence from the judicial system and separation of powers are accepted... in agreement with the formal interpretation of the Sharia».

Consequently, these followers of the formalist standpoint deny the possibility of the establishment of one democratic constitution in Indonesia based on four principles7:

1) The formalists argued that the contents of the Sharia are immutable and any application of a democratic constitution coming from the people would be wrong.

2) They defended the divine origin of the Sharia and not of the people.

6. HOSEN Nadirsyah, "Sharia and constitutional reform» in Sharia and Constitutional reform in Indonesia, Singapur, Iseas, 2007, pp.28-58

7. HOSEN Nadirsyah, «Sharia and constitutional reform» in Sharia and Constitutional reform in Indonesia, Singapur, Iseas, 2007, pp.28-58 
As such, this law of God could not be modified by a human being, and consequently the people were not sovereign and a constitution could not be applied.

3) They refused the separation between Islam and the State that defends constitutionalism arguing that the Sharia does not separate religion and State.

4) They defended the total character of the Sharia in the sense that it covers all the aspects of life, unlike the constitution that they consider incomplete. Their ultimate goal was establishing an Islamic State.

On the contrary, the substantial approach argued that «the Sharia should be re-interpreted according to democracy and constitutionalism».

It was in the Committee for the Preparation of Independence of Indonesia (BPUPKI) ${ }^{8}$ that this war between the two groups happened. Their arguments were framed as follows: For this nationalistic group it was impossible to establish the new Indonesian State as an Islamic State because the different religious minorities which lived in various parts of Indonesia would feel threatened. Because of that they would not join the new potential Indonesia and would instead attempt to establish new countries. This is the same situation that is taking place now with the regions of Maluku and Papua, etc. For this group the unity of the country and defence of nationalism prevailed over the establishment of an Islamic State. In addition to this desire for unity, there was a religious difference between the two groups with the nationalist approach claiming that the Koran as well as the Sunna did not indicate in a precise way that the Muslims had to live under a specific political structure or create an Islamic State. For them, the future Indonesian State had to be based in the Koran and the Sunna as guides and inspiration, but not more. Although the nationalistic group rejected the establishment of

8. The BPUPKI was established on March 1, 1945 within the Japanese period to prepare for the independence of Indonesia before the imminent defeat of Japan in World War II. The Bahasa Indonesia version is: penyelidik Badan usaha persiapan kemerdekaan Indonesia. Later known as PPKI, Panitia Persiaparan Kemerdekaan Indonesia, or Committee for the Preparation of Independence from Indonesia. 
an Islamic State and defended first of all the unitary character of Indonesia that did not mean that they refused the role of religion in the political life of the country and especially the role of the Muslim religion.

In contrast, the Islamist group defended both the inclusion of Islam as the official religion of the State, as well as the establishment of an Islamic State. There were three arguments that were given to defend their position:

1) the total character of Islam. Islam was perceived as an integral system that covered all the human activities and consequently the government action could not escape that fact.

2) The moral superiority of Islam with regard to the other ideologies and religions. They defended Islam as the definitive religion.

3) Because $85 \%$ of the population of Indonesia professed the Muslim religion, it was obligatory and necessary that Islam was the official religion of the State.

These three principles are concentrated in the following declarations of the leader of the Islamist group, Mohamed Natsir" ; "The State is not a goal but a tool. In principle, the matters of the State are an integral part of Islam». "The Pancasila as the philosophy of State is for us (the Islamic community) dark and does not have to say anything to the soul of the Islamic community, which already has a clear, definitive and complete ideology, which is already in the hearts of the Indonesians as a living inspiration and a source of force, this is the Islam. To change the Islamic ideology for the Pancasila is, for the Muslims, to enter the emptiness».The fight between both groups culminated in the creation of the Pancasila10 (official philosophy of the State). The Pancasila is composed of five principles that were expressed by Sukarno in his famous speech titled «The

\footnotetext{
9. Idem

10. The discourse where Sukarno announces the birth of the Pancasila is found at: Pidato Soekarno: Lahirnya Pancasila. http://kepustakaan-presiden.pnri.go.id/speeches_clipping/ index.asp?box=detail\&from_box=list_245\&id=39\&page=8\&presiden=\&search_ presiden=\&search_tag=\&search_keyword=\&subjek=\&author=\&activation_status=
} 
birth of the Pancasila» carried out on the 22nd of June 1945 before the Committee for the Preparation of Independence of Indonesia. These five principles were ${ }^{11}$ :

1) Nationalism. For the nationalistic group, of which Sukarno was the main figure, the unity of Indonesia was the primary goal and considered nonnegotiable. For that reason they guaranteed freedom to the different religious confessions and cultures that were found in the East of the country in exchange for their loyalty to the new Indonesian State. The unity of Indonesia was vital.

2) Humanitarianism. This principle defended the equality and respect between all the citizens of Indonesia.

3) Social justice. This refers to the guarantee to all the citizens of Indonesia of economic welfare.

4) Democracy. Sukarno was conscious that the principles of democracy next to Islamic religion were going to create the most tension in the minds of the Islamist group. With the aim of adapting the Islamist group to a democratic Indonesia, Sukarno linked both principles to several concepts of Islam. Two important concepts of Islam for making the link to democracy were that of deliberation (musyawaran) to arrive at consensus (mufakat).

5) Belief in God. The last principle established the belief in a God without specifying one, which Sukarno hoped would make the new State appeal to the Islamist group as well as the other religious groups. The Indonesian constitution does not establish any religion as official but at the same time it recognizes Islam, Christianity, Protestantism, Hinduism and Buddhism as religions that can be practiced freely.

11. RAMAGE Douglas, «Origins of discourse: politics and ideology since 1945» in Democracy, Islam and the ideology of tolerance, UK, Routledge, 1997, 10-44 
The debate and the struggle between the nationalistic group and the Islamist group persisted during all the stage before independence, and only days before the declaration of independence on the 17th of August 1945 an agreement was reached between both groups. To facilitate the pact ${ }^{12}$ between both groups a special committee was created in the Committee for the Preparation of Independence of Indonesia that comprised leaders of both groups such as Sukarno, Hatta, Muzzakar and Tjokrosujoiso. The committee worked together and on the 22nd of June 1945 the commitment reached between both groups was introduced. It was decided to accept the five principles enunciated in the Pancasila on the part of both but with two basic changes that the Islamist group would accept.

The first change referred to the order of the principles situating religion in the first place and not in the last, in the preamble as well as in the article 29 , thus giving a greater positioning of the religious principle. The second change added to the religious principle «Belief in one God», the famous seven words that compose the Jakarta Charter ${ }^{13}$, «with the duty to follow the Sharia for its followers». These changes are very interesting because due to the peace process at present in the province of Aceh this amendment has been introduced that gives Aceh an important autonomy in the legal area. This aspect is important since it has accommodated desires for religiousness among the community of Aceh in Indonesia.

These two modifications introduced profound changes in the new form of the future State. In practice it meant that the new Indonesian State was established as an Islamic State where Islam would not only be the moral and spiritual guide, as advocated by the members of the nationalistic group, but also the base on which the power of the State was established.

This change in the order and content of Pancasila had a very short life revealing the fragility of the consensus. These changes were removed the

\footnotetext{
12. EFFENDY Bathiar, «Explaining the uneasy relationship political antagonism between Islam and the State in Indonesia» in Islam and the State in Indonesia, New York, Ohio University Press, 2003, 13-52.

13. The Jakarta Charter is named in Bahasa Indonesia as Piagan Jakarta. The complete phrase is «dengan kewajiban menjalankan syariah Islam bagi pemeluk-pemeluknya».
} 
day after the declaration of independence of Indonesia since Mohamed Hatta was told by a Japanese officer that some areas of eastern Indonesia, including Maluku, Bali island, etc, would not join the new state because it did not establish legal equality between different religions in the country and placed Islam as the official state religion ${ }^{14}$. In this new Indonesian state religious minorities did not feel part ${ }^{15}$ of the new political reality.

Sukarno's fear of failing to establish a unified Indonesia with possible international pressure not to support Islamist forces motivated him to change again the contents of the Indonesia constitution and the withdrawal of the Jakarta Charter of both the preamble and Article 29 that deal with religion. The withdrawal of the Jakarta Charter meant the elimination of the principal amendment that that had made possible the acceptance by the Islamist group of the new judicial law. The response to this critical change resulted in leaving the religious principle first and adding to the principle of belief in God the phrase «Yang maha esa», or he who is the one. Sukarno was aware that the exclusion of the Jakarta Charter in the constitution would have a tremendous impact on the Islamist group, so added this sentence about the oneness of God. It was an attempt to please and accommodate Islamists while creating a firm base for religious plurality ${ }^{16}$. But It was not enough and the withdrawal of the Jakarta Charter was considered by many within the Islamist group as a defeat and a huge loss for many within the Islamist bloc. This principle is basic to understanding the entire ideological framework that underpins Indonesia and the religious tensions that currently exist between Aceh and Indonesia.

After the removal of the Jakarta Charter, they would close the constitutional process by creating a religious state. That is, they chose a

14. HOOKER Mb and LINDSEY Tim in "public faces of Sharia» in Studia Islamika voll 10, $\mathrm{n}^{\mathrm{o}}{ }_{1}$ $2003, \mathrm{p} 29$.

15. EFFENDY Bathiar, «Explaining the uneasy relationship political antagonism between Islam and the State in Indonesia» in Islam and the State in Indonesia, New York, Ohio University Press, 2003, 30

16. Azra Azyumardi, «Pluralism, co-existence and religious harmony» at http:// azyumardiazra.com/index.php?option=com_docman\&task=cat_view\&gid=20\&dir=DESC\& order $=$ date $\&$ limit $=10 \&$ limitstart $=0$ accedido $22-01-08$ 
middle path between a Western-style secular state and an Islamic state. More specifically, using the Wolfian ${ }^{17}$ typology for classifying different types of relationships between state and religion they opted to establish a model of «utility» where the spiritual worlds (Religion) and material (state) coexist subordinated to one another, not giving either a church of the state that dominates the spiritual pole or a confessional state that dominates the material pole. This model of relationships is where it is most useful to understand the changes of the influence of one or the other and where discrepancies may exist in the areas of management and influence between them. I refer to what are termed as «mixed materials» or materials which require management of both poles. The religious state symbolized the unrealized desire of the nationalist group to accommodate the Islamist group to the new Indonesian State. While not declaring any religion as official, they accepted the existence of the five religions in Indonesia. This recognition enabled almost all the various religious communities in Indonesia to feel comfortable within the new political framework.

Sukarno's decision to withdraw the Jakarta charter from the constitution of Indonesia generated different reactions by the Islamist group. One reaction was to feel proud of the sacrifice made by them in favour of the unity of Indonesia. Another group was deeply disappointed and betrayed and opted for armed struggle, which was the case of Darul Islam ${ }^{18}$ with the aim of establishing an Islamic state in Indonesia. A final group decided to wait until the next elections to regain lost political conquests, as was the case of the large Indonesian Islamic party, Masyumi. None of them achieved progress towards their goals and only accumulated failures in their attempts to establish an Islamic state in Indonesia.

The withdrawal of the Jakarta Charter in the Indonesian constitution marked the first of a long losing streak of political Islam in its attempts to win power and establish the legal union between Islam and the state.

17. LLAMAZARES Dionisio, «Modelo de utilidad» in Derecho eclesiástico del Estado: derecho de la libertad de conciencia, Universidad Complutense de Madrid, Madrid, 1989, pp.58-62.

18. International crisis group «Recycling Militants in Indonesia: Darul Islam and the Australian Embassy Bombing» at http://www.crisisgroup.org/home/index.cfm?id=328o\&l=1 
Of these three types of reactions, it is necessary to focus on Darul Islam because it is directly related to Aceh. In 1948 an Islamist rebellion of Darul Islam (House of Islam) broke out that was led by Kartosuwiryo with the aim of establishing an Islamic state in West Java. This was a bloody rebellion in their struggle against the central power and lasted until 1962 and was also carried out in other parts of Indonesia, such as South Sulawesi and Aceh. In the case of Aceh, the rebellion broke out in 1953 against the central power of Indonesia. The rebellion ended with a promise of a special administrative status for the region that was never fulfilled. Aceh followed the West Java revolt with the desire to triumph against the Indonesian state in the hopes that it would disintegrate. This idea of disintegration has been maintained by GAM during years of conflict. The basic premise was that the state of Indonesia due to its special geographical, religious, and ethnic diversity would disintegrate. Therefore, resistance was necessary so that Aceh could recover the status of freedom lost in 1873 .

This attempt failed, but showed two critical variables in the development of the Aceh-Indonesia conflict. On the one hand, it showed that the latent conflict for 50 years after its final defeat in 1904 had resurfaced. On the other hand, it initiated again a second cycle of violence that lasted until 2005 with the signing of the Memorandum of Understanding between GAM and the Indonesian government.

\subsection{ACEH, SUHARTO AND THE PERIOD OF REFORM}

Once Sukarno stepped down in 1965, Suharto would take power and due to the repressive and centralist policies of the dictator the conflict in Aceh evolved into its bloodiest stage. This is important because it was throughout the Suharto dictatorship when the conflict was settled and there was the birth of GAM as an organization representing the nationalist community in Aceh.

In the Suharto era there was a threefold process that encouraged the separatist phenomenon in Aceh. These three elements are: 1) Suharto continued with a process of administrative centralization of the country 
causing in Aceh an increased aversion to the central power of Indonesia, 2) there was a widespread violation of human rights throughout the country and particularly in Aceh, leaving a great hatred within the people of Aceh, 3) third, and this factor has to be added to the previous two, Suharto continued usurpation of natural, oil, gas, marine and timber resources from Aceh. Taking natural resources and the repression and political centralization of the country was based on Suharto's decision to give political stability and economic development to Indonesia. To do this, Suharto argued that the greatest enemies to achieve those objectives were Islamism represented in political Islam and jihadism, communism, symbolized by the Communist Party of Indonesia and separatism principally symbolized in Aceh and less so in Papua. Therefore, Aceh became an area of special surveillance and control as Suharto would never allow one of Indonesdia's main sources of wealth to disappear.

This threefold process triggered by Suharto provoked furious reaction in Aceh which was transformed into the creation of GAM in 1969 by Hasan Di Tiro, a former member of Darul Islam, with the aim of achieving independence from Indonesia. Later, in the year 1976 they declared Aceh's independence from the Republic of Indonesia ${ }^{19}$. From that moment began a stage of direct armed confrontation between the Indonesian military or Tentara Nasional Indonesia (TNI) and GAM that only ended with the signing of the Memorandum of Understanding in 2005.

The second event which intensified the struggle between GAM and the TNI was the return during the years 1989 and 1990 of old combatants of GAM coming from Libya where, as in other parts of the Muslim world, they started a struggle against the central power of their respective countries.

This return of combatants caused a significant deterioration of the situation in Aceh that caused Suharto's response of establishing the Daerah Operasi Militer ${ }^{20}$ or District of military operations (DOM). As expected, this

\footnotetext{
19. Declaration of independence of Aceh - Sumatra December 4, 1976 http://acehnet.tripod. com/declare.htm

20. Tempo Interaktif «Operasi Militer di Aceh» at http://www.tempointeraktif.com/hg/ timeline/2004/07/12/tml,20040712-01,id.html
} 
categorization of Aceh left hundreds dead and displaced throughout the region. With the establishment of the DOM arrived the introduction of martial law in the province creating a lack of protection for the citizens of Aceh and a smokescreen for the soldiers who participated in military operations in the area. The result of the establishment of the DOM and the intensification of fighting caused about 10,000 deaths until the ending of the DOM in 1998 with the fall of Suharto. Even though the military pressure was very high, all the military period of the DOM was insufficient to crush GAM and, on the contrary, gave it reasons to continue struggling ${ }^{21}$.

The fall of Suharto and the arrival of the period of the «Reform» ${ }^{22}$ in Indonesia brought winds of change in the politics of Indonesia. Not only did new people lead the executive transition to democracy, such as Habibie, but new policies and ideas began to develop about how to deal with and end the conflict in Aceh.

The first major result of the arrival of democracy in Indonesia was the end of the DOM and the beginning of charting a new course to solving the conflict in Aceh.

The second consequence was that the interim President Habibie asked forgiveness for the first time to the society of Aceh for all the damage caused and for the abuses committed by security forces in Aceh. At the same time the national parliament passed a law giving greater powers to the provincial government of Aceh on education, religion, etc. in an attempt to reconcile the positions. Alongside this measure, the third Indonesian parliamentary seat after the Congress and the Senate, Majelis Permusyawaratan Rakyat, or Consultative Advisory of the People (MPR) passed a special autonomy law for Aceh.

All these movements were carried out unilaterally by the Government of Indonesia and without the explicit acceptance of GAM as a political

21. TJHIN Christine Susana «Post Tsunami Reconstruction and Peace Building in Aceh:

Political Impacts and Potential Risks« at http://www.csis.or.id/working_paper_file/59/ wps053.pdf

22. By the period of Reform I refer to the political cycle that began after the fall of Suharto in 1998 that led to the arrival of an interim president, Habibie, and the long-awaited arrival of democracy in Indonesia. 
interlocutor. This lack of involvement meant that these measures were not welcome in Aceh since they failed to recognize the political leadership of GAM in Aceh. All these attempts were not sufficient to achieve peace in the region leading to the forging of a new path for Aceh that would culminate in the Memorandum of Understanding of 2005. It was the beginning of a long and difficult road.

While these measures were taken, East Timor ${ }^{23}$ voted in a referendum for independence giving an important boost to the movement for independence in Aceh that also demanded equal treatment. But both the government and the army were not prepared to accept a double secession from Indonesia. This would have caused a huge destabilizing of the country and would have created situations impossible to control for the central political power.

The third major result of the arrival of the period of the «Reform» in Indonesia was the attempt by the first Indonesian President Abduraman Wahid or Gus Dur ${ }^{24}$ to start the first peace talks between GAM and the Indonesian Government, which as shown below, was not satisfactory but led the way for the next peace process in 2005 , the one that finally brought peace to Aceh.

The fourth consequence and perhaps most importantly, was that with the advent of democracy began the long-awaited decentralization policies advocated by many in Indonesia. The first decentralization laws were introduced in 1999 by law 22 and 25, but did not go into effect until January 2001 and were subsequently repealed by Act 32 in 2004 on «the regional Government» ${ }^{25}$. This decentralization made it possible ${ }^{26}$ for individual

23. I recommend visiting the website of the UN about East Timor at http://www.un.org/ peace/etimor99/etimor.htm

24. Gus Dur is considered the ideological father of liberal Islam in Indonesia. His desire to advance peace in Aceh deserves the highest consideration. Note also his desire to improve diplomatic relations with Israel. His departure as president was a blow to the peace process.

25. Law of regional decentralization «Menjada pemilu jurdil». http://ndijurdil.ndi.org/ Law_32_2004_RegionalGovernance_EnglishVersion.pdf 21-11-07

26. RASYID Ryaas, «Regional autonomy and local politics in Indonesia» in Aspinall, Edward, Local power and politics in Indonesia. Decentralization\&Democratizacion, Iseas, Singapur, 2003, 63-71 
states as well as Indonesian provinces to establish perdas (local regulations) in various basic areas, such as agriculture, health, civil registration, etc. The key change in this process of decentralization was that for the first time and far from the central pressure of Suharto, the process of political and administrative decentralization was observed without linking it to separatism or independence as had been done previously. Decentralization in Indonesia did not mean to separate, but to unify Indonesia. This information is vital because it allowed during the completion of the second peace process for the administrative autonomy granted to Aceh in several areas to be seen without fear from Indonesian negotiators and especially without fear of criticism from the most ardent nationalists. 


\section{FIRST PEACE PROCESS}

The arrival of democracy entailed a change of political regime that brought in new actors, ideas and policies for managing the conflict in Aceh. Keep in mind that since 1873, the year in which the sultanate of Aceh was invaded, until the year 2000 there was no attempt by the various political administrations to establish a new framework of coexistence between the region of Aceh and state. And then Abduraman Wahid, also known as Gus Dur, carried out the first peace talks, which can be divided into two distinct phases.

The first round of talks was held from January 2000 through May of that year. The second round of talks was held in May 2002. This first attempt at a peaceful solution in Aceh was flawed but it did show several factors that marked the way for a solid and lasting peace in the region.

These first peace talks in Geneva were carried out between GAM and the Indonesian Government through the mediation of the Henry Dunant Center in Geneva ${ }^{27}$. These initial talks held between March and May of 2000 bore fruit with the declaration of a «Joint understanding on humanitarian pause for Aceh» issued on 12 May 2000. The validity of this agreement was three months long and was extended another three months in September of that year.

This agreement was essentially threefold: 1) facilitating humanitarian assistance to victims of conflict, 2) establishing measures of trust between both parties, 3) and reducing violence in the area. To achieve these objectives a series of committees and verification teams were established to verify the implementation of the peace process. Among these were: 1) the Joint Forum comprising members of the Government of Indonesia and GAM in order to verify the development process, 2) the Joint Committee for Security Modalities (JCSM) to check safety standards in the area, 3) the

27. For details of the peace talks between GAM and the Indonesian government see the official section of the peace process from the standpoint of the Henry Dunant Center in http://www. hdcentre.org/projects/aceh-indonesia 
Joint Committee for Humanitarian Action (JCHA) to guide humanitarian action, 4) two teams of independent verification about security and humanitarian issues with the objective of continuing to implement the process and 5) four-team district verification with the aim of checking the development of the peace process in the various areas of Aceh. A good start to the peace process was found in January 2001 with the signing of the «Provisional Understanding» in which various aspects were recognized such as encounters between military members from both sides to develop confidence-building measures and measures to reduce the violence, etc. At the same time and to check the development of this agreement the Joint Council was established with members from both parties. While the Joint Council met on two occasions, February and June 2001, the situation in Aceh worsened. The first positive indication after signing the «Joint Understanding on Humanitarian Pause for Aceh» was a decrease in violence, but this situation quickly turned into a resurgence of armed actions by both sides due to lack of trust between the parties and the large differences between the aims of the two opponents. On top of that, the situation with the government of Jakarta with Gus Dur about to resign did not favour the settlement of peace in Aceh.

This agreement did not work for two reasons. First, the violence continued to exist because the army remained as a free entity within the Indonesian political game and GAM itself at no time left its armed activities. That is, none of the key players in the conflict were willing to abandon the armed struggle. Second, Gus Dur was going through a period of political instability that led to the end of his presidency. Therefore, three factors emerged as key to the future: strong political leadership, realism in the objectives of both GAM and the government and control over the army.

On the role of the $\operatorname{army}^{28}$, we must remember that East Timor had gained independence, and the TNI was not willing to suffer through another political defeat that would marginalize their role in Indonesia. Therefore,

28. ISIS «The East Timor crisis» at http://www.iiss.org/publications/strategic-comments/ past-issues/volume-5---1999/volume-5---issue-8/the-east-timor-crisis/ 
the East Timor factor was very important in the failure of this first round of negotiations.

Once the first phase of the first peace talks failed to redress the situation, a second round of talks started again in Geneva on the $8^{\text {th }}$ and $9^{\text {th }}$ of May 2002 that were achieved through the COHA statement ${ }^{29}$ or Cessation of Hostilities Framework Agreement on 2 December 2002. The objective of this agreement like the earlier attempt was to reduce the intensity of violence in the area through the turning over of weapons by GAM, as well as a change in the army's mission in the area from an element of attack to defence. The starting point of COHA was the autonomy law signed by Habibie in 1999. The idea was that based on this law, they could build an autonomous Aceh within Indonesia. However, this aspect was an unrealistic goal because of the demanding objectives of GAM at that time from the government of Indonesia.

Within the COHA agreement three new levers to seek peace were constructed: first, the establishment of a verification mission of the agreement consisting of members of GAM, the Indonesian government and the Henry Dunant Center. The second lever was the establishment of the first «Peace Zones» or what might be called as safe areas to work on issues of reconstruction and humanitarian relief. In total there were five safe areas. The last lever refers to the emphasis COHA placed on the dissemination of information concerning the peace process. An intense contact with the population was made to explain the peace process including newsletters and other means of communication.

Despite these good actions, a new peace did not form as violence picked up again showing the limitations of both parties to achieve a negotiated peace.

The final act of this first peace process was in Tokyo during the $17^{\text {th }}$ and $18^{\text {th }}$ of May 2003 where representatives from both sides met to reach an agreement that would save the COHA. This was not achieved, and the

29. GRIFFITHS Martin «Giving peace a chance to take root in Aceh» at http://www.hdcentre. org/files/Giving\%2opeace\%20a\%20chance\%20Aceh\%2028\%20Feb\%2003_o.pdf 
Indonesian government's proposal to GAM to renounce independence as a way to continue the peace process was rejected by GAM. The result was that Megawati Sukarnoputri ordered the establishment of martial law in Aceh and launched operation Terpadu on 18 May 2003 with the goal of eliminating the GAM. This attack resulted in the loss of hundreds of lives in Aceh and 150,000 people displaced internally.

\subsection{CAUSES OF FAILURE}

Undoubtedly, this second round of negotiations were a failure like the previous round of talks because GAM was far from abandoning its desire for independence while the Indonesian state was in no way ready to allow a free and independent Aceh. Strategists on both sides never stopped planning for armed struggle.

But above all this first peace process failed because it was misguided from the start. The primary objectives of this peace process were lowering military tensions, facilitating disarmament, developing measures of trust, etc., but did not deal with the key theme on the status of Aceh within the country $^{30}$. This point was crucial because it was the main historical obstacle to the peace process. The large distance ${ }^{31}$ between the objectives of both on this point put an end to the peace process. This fact was established as a mistake because it avoided the key point of the conflict. This lesson was learned in the second peace process which was negotiated under the premise that negotiation was not completed until all the points were closed.

This first peace process included three variables that caused its failure:

1) First, the lack of strong political leadership to push the peace talks. This lack of political leadership must be implicated in the control over the army. TNI throughout the Suharto era enjoyed the highest privileges and

30. ASPINALL Edward and CROUCH Harold « The Aceh peace process: why it failed» at http://www.eastwestcenter.org/fileadmin/stored/pdfs/PSoo1.pdf

31. Idem 
the ultimate power and became an important political actor in the early years of Indonesian political life. Therefore, it needed a president who could control and dominate the army and above all make it an organization under civil control. To this fact must be added the loss of East Timor where the army violated human rights, and where the army in those years still described itself as the defender of the unity of Indonesia. The army's loss marked a serious failure and therefore they could not consider losing another region.

2) Other key variable was the weakness of the Henry Dunant Center in conducting the negotiations. Just remember that this was the centre's first international experience in conflict management, and the results showed its lack of experience in handling the two conflicting parties.

3) Finally, although the presence of the Henry Dunant Center was important for the introduction of international influence in conflict management, what was more significant was that there was no international involvement so great and massive as the one reached with the Aceh Monitoring Mission later. In other words, there was no clear and concise support of the international community towards this first peace process.

All these variables were taken into account at the beginning of the second peace process that culminated in the signing of the Memorandum of Understanding and the subsequent development of LOGA. 


\section{SECOND PEACE PROCESS}

Once the first two rounds of negotiations of the peace process failed the major military offensive against GAM bases in Aceh began. The stated objective of the Government of Megawati Sukarnoputri was to destroy GAM. It went from a situation of trying to find a negotiated solution to the conflict to a military solution par excellence. The operation was named as Terpadu $^{32}$ or integrated. The two main consequences of this operation were mentioned before: on the one hand, while there was a reduction in the number of GAM fighters, it remained intact again proving the ability of the organization to regenerate and survive. This is important because it sent a clear message to the political establishment in Jakarta that GAM annihilation through military means was impossible. At the same time, the high number of casualties among the civilian population created a strong resentment among the Acehnese people that united GAM and increased rejection of the central government.

In this situation of war there was one of the worst natural disasters in history that occurred on 26 December 2004 with the arrival of the tsunami in Indonesia. The giant waves that killed 150,000 people had a pacifying effect on the conflict. First, after so much death and destruction already, Aceh society reached its highest levels of suffering. This pressure made both GAM and the central government seek a peaceful and negotiated solution to the conflict to end violence. Only in a situation of peace was it possible to rebuild Aceh. This is important in developing the history of the conflict because both sides were forced to reduce their claims.

In the case of GAM, the breakthrough that facilitated the negotiation was assuming greater political autonomy for Aceh and economic management but within the context of Indonesia. In the Indonesian case, they decided to bet heavily on a peaceful solution to guarantee the end of

32. Sukma RIZAL «Security Operations in Aceh: Goals, Consequences, and Lessons» at http://www.eastwestcenter.org/fileadmin/stored/pdfs/PSoo3.pdf 
hostilities and the presence of Aceh in Indonesia. Also important was that the Terpadu operation that was taking its course at that time was suspended.

At the same time, the closed off Aceh province had to be opened to international aid before the Indonesian government's inability to help the population in such a great disaster. This entry of various international NGOs had a deterrent effect on both sides as all military acts by any of them were rapidly becoming internationalized going against their military objectives. Therefore, the emergence of the Tsunami had one positive effect for Aceh and for Indonesia that both had to modify their previous positions and seek points of agreement for peace.

Furthermore, the destruction caused by the tsunami highlighted a fact that eventually pushed GAM to abandon their desire for independence of the country. This fact was the limited ability of GAM to manage its own state $^{33}$. In the areas GAM controlled, their resources were focused on some weak health and educational services and a limited fiscal capacity resulting from their weak economic growth. The consequences of the tsunami completely eliminated this small administrative network and completely destroyed their financial standing so that the chances of continuing the armed struggle for independence in Aceh became an unattainable dream. Therefore, the economic factor was important in advancing ideological positions of GAM.

This destruction of Aceh also had its impact in the larger community of Indonesia. Both the Indonesian government and army showed little ability to help the people of Aceh after the Tsunami. This showed that to continue a military campaign was impossible and the Indonesian state was forced to open up Aceh to the outside world in order to alleviate the suffering of the population.

This positive development for the peace process was combined with the leadership of the new government of Susilo Bambang Yudhoyono and Yusuf Kalla. SBY was no stranger to the problems in Aceh. He was security

33. KINGSBURY Damien «Peace Processes in Aceh and Sri Lanka: A Comparative Assessment « at http://www.securitychallenges.org.au/ArticlePDFs/vol3no2Kingsbury.pdf 
minister in the government of Megawati Sukarnoputri and was among the few who supported the development of ongoing negotiations with GAM, despite the problems in the region. But beyond that, the general was prestigious within the military in Indonesia and was among the few who could control the army and place it under civil power, as eventually happened. Therefore, one factor that derailed the previous peace process was overcome with the arrival of SBY. Also, SBY and his ministerial team concluded from seeing the results of the various military campaigns in Aceh that to end the armed group of GAM was impossible using force. It was therefore necessary to develop imaginative policies that facilitated the end of GAM and at the same time included their desire for independence for the region in a united Indonesia. The unity of Indonesia as a nation was essential for the Indonesian political establishment, especially if we consider that the negative experience of East Timor was very new at all levels of Indonesia's politics and military. The possibility that Indonesia as a country could disintegrate like Yugoslavia in the 9os was real and that was something SBY took into account because he had been present in Yugoslavia after the end of the Balkan wars in 1995. So he knew firsthand the ravages of war and above all he was aware that the danger of disintegration of the country was possible.

With regard to Kalla ${ }^{34}$, he was from Sulawesi, one of the areas that in previous years along with Maluku had developed significant inter-religious conflicts between Muslims and Catholics. He brought his experience managing this conflict to managing the conflict in Aceh. Therefore, they were two individuals trained and experienced and with important connections in the military and politics.

With SBY and Yusuf Kalla at the head of the peace process the first secret contacts with members of GAM in exile and in Indonesia itself were made. These first contacts were suspended by the tsunami and quickly taken up after it. To replace the Henry Dunant Center this time it was the Crisis

34. HAJRAMURNI Andi «Kalla ready to play role as peace broker» at http://www. thejakartapost.com/news/2009/o9/28/kalla-ready-play-role-peace-broker.html 
Management Initiative 35 that became the negotiator of both GAM and the Indonesian Government.

This new climate of understanding between GAM and the Indonesian government resulted in the statement of 17 July 2005 which said «The parties are largely convinced that only a peaceful settlement of the conflict can rebuild Aceh after the tsunami disaster on 26 December 2004». So the good intentions of both parties came to fruition in the second phase of the Aceh peace process which we know ended with the signing of the Memorandum of Understanding. These consisted of five rounds of negotiations in Helsinki and lasted from 27 January 2005 to July 17 of that year. What made possible the development of the negotiations were: the political leadership of Susilo Bambang, the control of the army, the advance of both parties' positions, the acceptance of autonomy, the end of the armed struggle by GAM, and the rejection of the military path suggesting a greater degree of political power and political participation.

\subsection{ESTABLISHMENT OF THE MEMORANDUM OF UNDERSTANDING ${ }^{36}$}

Peace talks between GAM and the Indonesian Government ended on 15 August 2005 with the signing of the Memorandum of Understanding between the two groups (see the appendix). The items of the peace agreement are grouped into six sections:

1) Government of Aceh

2) Human Rights

3) Amnesty and reintegration in the society

4) Agreements of security

5) Establishment of the Aceh Monitoring Mission

6) Resolution of Disputes

35. http://www.cmi.fi/?content=aceh_project

36. To see the official document of the MoU, see «Memorandum of Understanding Between the Government of the Republic of Indonesia and the Free Aceh Movement» at http://www. cmi.fi/files/Aceh_MoU.pdf 
The agreements aimed to neutralize three major grievances of Acehnese society: economic resources, political autonomy and greater importance of Islam in Acehnese society.

The first point of the Memorandum of Understanding refers to the government of Aceh because it reflects the main contents that have brought peace to Aceh. This was accomplished in four important ways.

First, in the Memorandum of Understanding it was established that they would make a law on the governing of Aceh which would regulate the organic apparatus of Aceh. This point is expanded on later.

The second important contribution to the establishment of government in Aceh concerns political participation. Through the Memorandum of Understanding on Aceh local parties can now be nominated both to the local elections, an opportunity that took place in the $2006^{37}$ gubernatorial election, as well as to the legislative elections to form the parliament of Aceh. Facilitating political participation in Aceh opened a political and especially peaceful path for former GAM members to continue their «struggle» through peaceful and democratic ways. Also, enabling the formation of local parties created the possibility that the struggle carried out by GAM for 30 years could acquire political legitimacy as it did then to get popular support in both the gubernatorial election and in the legislation. Opening up political participation thus guaranteed the presence of nationalism in Aceh's political life. In sum, the possibility to participate in elections facilitated the transformation of the military power of GAM into the political power of the Aceh Party.

The third point deals with economy and involves a long awaited aspiration of Acehnese society to have better access to the benefits of natural resources in the region. There existed within the society of Aceh a very pessimistic view on the theft by the central government of the riches of Aceh, namely oil, natural gas, various marine resources, lumber, etc.

37. WILLIANSON Lucy «Aceh votes for major change» at http://news.bbc.co.uk/2/hi/asiapacific/6171265.stm 
Fourth, the section of government in Aceh was centred on the right to integrate the Qanun or Islamic law in the legal system in Aceh.

The second major area of the Memorandum of Understanding is focused on Human Rights. The main point here was the establishment of a Commission for Truth and Reconciliation in order to establish the human rights violations committed and fostering reconciliation between the two societies.

The third area of the agreement focused on the amnesty and reintegration into society of former GAM combatants. There are two aspects to be highlighted. The first concerns the general amnesty that was granted to all members of GAM and political prisoners. The second point was that a method was sought to integrate former GAM members in the society, a feature which is still quite problematic and has not been achieved.

The fourth area of the Memorandum of Understanding is focused on security in the region. The main section focuses on the demobilization of 3,000 GAM members while reducing the presence of Indonesian troops in the region to 14,700 soldiers and 9,100 policemen. This number of troops has always been strongly criticized by the nationalist movement of Aceh as extremely high for a peaceful situation.

The fifth section focuses on the establishment of the Aceh Monitoring Mission ${ }^{38}$. The performance of the Aceh Monitoring Mission has been a cornerstone in consolidating peace in Aceh and demonstrates the effectiveness of one of EU's soft power actions outside its continental area. The performance of the Aceh Monitoring Mission was instrumental in implementing the MoU. This joint undertaking of the EU plus Norway and Switzerland and five ASEAN countries (Thailand, Malaysia, Brunei, Philippines and Singapore) is one of the main examples of cooperation on peace and security between these two major regional political bodies in Europe and Asia and provides a model for future conflicts in the region.

This mission lasted from 15 September 2005 to 15 December 2006. Its main objective was to be a facilitator of the implementation of the MoU

38. For more information visit the web page of the organization at: http://www.aceh-mm. org/ 
signed between the Government of Indonesia and GAM. The main characteristics of the European and Asian joint mission are that it was civilian, not military, impartial and above all a driving force for implementing the MoU. This is very important since the Aceh Monitoring Mission was instructed to seal the agreement between both parties.

Another feature is that the mission was extremely pro-active in continual contact with both parties and proposing ideas for the proper conduct of peace. While it began on September 15th, from the day of signing the Memorandum of Understanding there existed an initial action agreed upon at the Initial Monitoring Presence IMP. ${ }^{39}$ This action contributed to the tasks of verification and to the enforcement of the process of peace to begin from the first moment preventing eruptions of violence and further complications to the process of peace.

In addition to facilitating the implementation of the MoU, the Aceh Monitoring Mission had other objectives, among which were ensuring the guarantee for the disarmament of the various armed groups in Aceh, to verify the reduction of the Indonesian police and military personnel in Aceh and to study the violations of the MoU by either party.

Finally the Aceh Monitoring Mission was also responsible for facilitating the reintegration of former GAM members into society, a feature which still remains unresolved, verify the creation of a new legislative power that embodies the new political autonomy of Aceh within Indonesia and finally, assure human rights in Aceh.

The last point of the MoU focuses on the settlement of disputes over its implementation. This point is related to the Aceh Monitoring Mission and sets three levels when solving disputes. These three levels are the following from less to more serious: 1) by the Aceh Monitoring Mission, 2) by the head of the operation and the leaders of both parties and 3) by the interior minister of Indonesia, the GAM leader and the leader of the ICM.

39. SOLANA Javier «EU High Representative for the CFSP, welcomes the signature of the Memorandum of Understanding between the Government of Indonesia and the Free Aceh Movement» http://www.consilium.europa.eu/ueDocs/cms_Data/docs/pressData/en/ declarations/85995.pdf 


\section{DEVELOPMENT OF THE LAW ON THE GOVERNING OF ACEH-LOGA 40}

As has been stated in the Memorandum of Understanding, an important factor of it was the development of LOGA or Law on Governing of Aceh. This law must be based on the Memorandum of Understanding agreed between GAM and the Indonesian government and the proposal of LOGA developed by the Aceh regional parliament. This new LOGA was established by the parliament of Jakarta on 31 March 2006, and as I stated before is key to consolidating peace in Aceh because it transforms what was agreed on in the Memorandum of Understanding into binding legal rules.

The main contents of LOGA relate to administrative decentralization and political participation. The final alignment of these two principles in LOGA and in Aceh is the essence of this paper and will be explained in more depth.

- The principle relating to government concerns how the government of Aceh came to have jurisdiction over all matters that are not under central government authority, such as defence, justice, security, fiscal and monetary policy and some aspects of religion and so on. The remaining functions were to be administered by the government of Aceh. An important point here is that the management of religion became a matter for Aceh, giving expression to one of the wishes of Aceh society to develop a more conservative Islam than the rest of the country and overall becoming more present throughout their society. The religious theme would be complemented by the development of Sharia law in Aceh.

- The principle related to international agreements, national laws and administrative measures states that when these measures affect Aceh they should be consulted with the Government of Aceh allowing it an important capacity for influencing the measures and above all demonstrating a distribution of political power.

40. A detailed explanation of the LOGA is found in MAY Bernhard «Law on the governing of Aceh» at http://www.conflictrecovery.org/bin/May-governing_aceh.ppt 
- The principle on the implementation of Sharia law refers to how the LOGA established that the Islamic Sharia in Aceh dictate civil law, criminal law, family law, etc. As I will discuss later, this is key in Aceh because today these changes are causing a great transformation. In today's Indonesia Sharia law applies in areas relating to divorce, marriage, etc. but not in the field of criminal law as it would mean punishments like whipping or stoning to death. Another controversial aspect of Islamic Sharia is an obligation of every follower of Islam in Aceh to be subject to the laws of the Islamic Sharia.

- The principle on political participation was one of the great successes of the peace process in Aceh because it allowed the establishment of local political parties in Aceh with a capacity to run for both local and national elections. Both of these possibilities were absolutely forbidden before. This cleared the way politically for the nationalist movement in Aceh to channel their struggle through political parties. It is interesting that the first elections held after the signing of Memorandum of Understanding, the elections for governor, only allowed the nomination of independent candidates rather than political parties in Aceh, a feature that was included in the legislative elections of April 2009. In this way a prominent member of GAM, Irwandi Yusuf, won elections as governor of Aceh as an independent candidate on 11 December 2006, not as a representative of any nationalist party of Aceh. Later, while in the legislative elections of 2009, the PA or Party of Aceh ${ }^{41}$, the political wing of GAM won $44 \%$ of the vote and 33 of the 68 members of parliament from Aceh clearly dominating the political landscape of the region. At the same time, the support from SBY to the peace process also impacted the results of both the legislative and presidential elections in Aceh, where the PD of SBY won 33\% of the votes in Aceh for the national elections and $94 \%$ of the vote in presidential elections. This dual behavior of voters, giving to the PA the autonomous power and the national power to the PD represented by SBY shows the great maturity

41. GELAR Andini and MOSTARON Tuty «Post election Aceh: an Outlook for peace and security» at http://www.rsis.edu.sg/publications/Perspective/RSISo732009.pdf 
of Acehnese society and above all a commitment to continuity among the promoters of the peace process in Aceh. This democratic impulse is a victory for all the creators of peace in the country.

- The principle of natural resource management is also an important point in the peace process as it responds to major historical demands of Aceh's society, particularly, greater access to the benefits of the great resources in Aceh. According to LOGA Aceh will receive $70 \%$ of the profits from oil and gas compared to $15 \%$ and $30.5 \%$ respectively from other regions and Aceh will receive 80\% of forest, marine, and mineral resources. this measure corrects a historical injustice in the economic situation of Aceh that was the plundering of the region for many years.

- The principle of Human Rights was based on LOGA giving permission for the creation of two institutions necessary for the consolidation of peace. First, a human rights court was established for prosecuting violations of human rights, and second, a commission for truth and reconciliation was created (yet to materialize).

- The principle concerning the police and the Armed Forces is the last major principle which regulated the LOGA. This principle is no less important for being last because the memory of police performance and especially the armed forces in Aceh produced a great aversion. Therefore, their new role and the control of them adapted to the new situation of peace in Aceh. With regard to the police the main change was that the police chief of Aceh while appointed by the national leadership of the police must have the approval of the governor of Aceh. Besides this, the security policies of the region should be coordinated by the governor and police chief. Regarding the military, it had the exclusive role of external defence of Aceh as well as other functions such as infrastructure development, disaster relief, etc. That is, it reduced the role of these forces in the region and also increased scrutiny of their activities. 


\section{PROBLEMS}

The implementation of the Aceh peace agreement brought an end to the violent struggle between the Indonesian state and the separatist movement GAM. This fact as we have seen before was a success and peace is more than settled. Although this effort has been completed, a number of issues related to implementing what was agreed on in the MoU are causing problems both in Aceh and throughout Indonesia, more specifically, the introduction of Sharia law or Islamic law in Aceh.

The best example is the adoption in September of a law ${ }^{42}$ for the parliament of Aceh that allows the stoning of prostitutes and people with bad moral behaviour. The introduction of this law is in line with the legal freedom granted by the Memorandum of Understanding and developed in the LOGA. Therefore it is legal, but produces a significant friction in the relationship between the central government and Aceh. This friction is expressed by both an increasing legal and ideological distance between Aceh and the Indonesian state that could produce a difficult assimilation between the two political entities. It is only the first step, but it is very significant how difficult at times it is to accommodate Aceh in Indonesia.

Today the application of the law is on hold but it will be crucial to see how the process unfolds. All this indicates some of the problems that can result from a decentralization policy. While Aceh must maintain their uniqueness within the State of Indonesia, there may be a growing gap between the two political entities that would be detrimental to the overall peace settlement. On the one hand, it would be detrimental to the region, and on the other hand, it might trigger a conflict, not armed as this scenario would be hard to imagine, but instead a legal conflict between Aceh and the Indonesian State.

42. SIMANJUNTAK Hotli «New Aceh council to rethink controversial stoning bylaw» at http://www.thejakartapost.com/news/2009/10/23/new-aceh-council-rethinkcontroversial-stoning-bylaw.html 
Other problems that remain open in Indonesia are the reintegration of former GAM combatants, the persistence of worrying levels of violence, the presence of weapons still not recovered from the GoI and the violation of Human Rights at a very low level that still prevails in Aceh. To this is added the delay in the formation of a Commission of Truth and Reconciliation and the special court of Human Rights collected and approved by the LOGA.

For the reintegration of GAM members, high levels of unemployment make it difficult to adapt to the new reality of Aceh. The efforts of both governments in Aceh and Indonesia have not been able to solve this problem, which is key to the complete stabilization of the region's population that otherwise might well take up arms again and not on behalf of a struggle for independence but as mobsters engaging in criminal activities.

Regarding the levels of violence in $\mathrm{Aceh}^{43}$, this has been reflected in threats to former GAM members by former members of the group that belong to a different political faction of GAM or exacerbated by Indonesian nationalists. Higher levels of violence occurred in the months before the legislative elections with the aim of intimidation, but the situation is now calmer.

The movement of weapons remains a serious problem in Aceh. The presence of weapons in the area for over 30 years of conflict has made the total elimination of them a complicated task. The launching of grenades at the PA headquarters, the assassination of members of the PA with firearms, etc. denotes that the persistence of weapons and calls for substantial work.

Finally, human rights violations in Aceh are extremely anecdotal but they occur, so there remains work to be done.

43. YUSUF Irwandi «Elections must be peaceful in Aceh» at http://www.thejakartapost.com/ news/2009/02/21/elections-must-be-peaceful-aceh.html 


\section{CONCLUSIONS}

The success of the Aceh peace process leads to several conclusions about the factors that made it possible.

- Leaders committed to peace. In this aspect two people should be pointed out. The first is the current prime minister of Indonesia, Susilo Bambang Yudhoyono. It is noteworthy that it was under the first year of his government when the peace agreement was produced. Susilo Bambang was a great expert on Aceh and the real possibilities that existed for a future breakup of Indonesia's Aceh as had happened before with East Timor. Moreover, he had a rich personal experience in the former Yugoslavia, so he was familiar with the disaster of a war caused by separatist tensions. So he put all their energies to work with the rest of his government to transform a war that had lasted 30 years into a peace agreement.

On the other side of the conflict, it is important to note Irwandi Yusuf. He knew how to renew with mastery the goals of his group until making them viable and acceptable especially for the Indonesian counterpart. His election as governor in the 2006 election was a reward for his organization for his commitment to peace and progress for the position of his group. Meanwhile, bipartisan support in past legislative and presidential elections of 2009 reaffirmed this support to both organizations.

- The importance of the period of «Reform». The fall of the dictator Suharto in Indonesia in 1998 not only marked the arrival of democracy in Indonesia. It was the initiation of new policies in Indonesia that replaced the previous ones. These changes must be emphasized, especially the decentralization policy of the country starting in 1999 and deepened in 2004. This decentralization process brought peace talks that were undertaken in 2005 with an environment conducive to the Indonesian public opinion to accept a higher level of political, economic and judicial autonomy for Aceh. This information is important because during the «reign» of Suharto Indonesia underwent a profound centralization in every way that was an incentive for the independence movement in Aceh. 
Therefore the country's decentralization process was a major push to establish a basis for peace in Aceh.

One idea that emerges strongly from this peace process is that in a country like Indonesia with extreme cultural, religious, linguistic, ethnic and geographic diversity there is a need for a deep level of administrative decentralization. The unity of the country managed under the mandates of Sukarno and Suharto was performed by means of force. Once the army was losing its strength the various conflicts that existed in Indonesia that were still latent emerged, such as the case of inter-religious conflicts in Maluku and Sulawesi, the case studied here in Aceh, Papua or the current conflict with the minority Ahmadiyah. The case of Aceh in particular shows that diversity can only be managed with political and administrative autonomy, while the use of force eventually leads to failure.

- Birth of East Timor. East Timor's separation from Indonesia in 1999 was a severe blow to Indonesia as a country but also for those who advocated centralized and radical ideas about how to deal with the issue of peripheral nationalist or separatist movements in Indonesia. That is when the policies of political decentralization in the country started to gather strength and were implemented with double cycle of decentralizing in the country in 1999 and 2004. So the East Timor case pushed the Indonesian political elite to present alternative policies to the various problems that threatened the unity of Indonesia such as Aceh, Maluku, Papua and maybe also the Hindu island of Bali. Possibly without the division of East Timor, peace in Aceh would not have arrived.

- The support from Europe and ASEAN. The Aceh Monitoring Mission working alongside European countries plus Switzerland and Norway and the ASEAN group of countries including the Philippines, Thailand, Brunei, Malaysia and Singapore was key in the settlement of the peace process. There are two aspects to highlight here. On the one hand, the impeccable work of the mission that knew how to maintain proper equidistance between the two sides so as to not arouse suspicion. On the other hand, the very existence of the Aceh Monitoring Mission just after the signing of the Memorandum of Understanding between GAM and the 
GoI became a barrier against possible outbreaks of armed struggle between two opponents.

- The triumph of politics. Suharto during his entire government and Megawati Sukarnoputri as well are representatives of the military means to resolve the conflict in Aceh, even though Megawati launched a peace process that was flawed. The failure in East Timor together with all the discredit suffered by the army fighting in Timor and the last days of Suharto left the national army in Indonesia or TNI in a weak position that it has not recovered from. This must be added to the military campaign against GAM in Aceh in 2002 and 2003 that left hundreds dead in Aceh and provoked a deep resentment among the population. But apart from producing this damage, the Government of Indonesia also produced a shift in strategy in the sense that it understood that military efforts after 30 years had simply been exhausted. That is when a new government appeared with new ideas that pushed a political path to the conflict in Aceh. But the exhaustion of the armed conflict not only took place within the area of Indonesia but also within the GAM. The key idea to be reached is that the GAM as an armed group was unable to defeat the Indonesian army. This exhaustion of both parties pushed for political channels to converge and result in the Memorandum of Understanding.

- The role of the Crisis Management Initiative. If the role of the EU and ASEAN was instrumental in post-conflict situations the role of the ICM in the stage before was vital. There are two immediate issues. First, the impulse that gave an impasse that occurred in Aceh. After the failure of the first peace process and the offensive launched by Megawati Sukarnoputri it was necessary to launch again a new peace process and this was initiated among others by the ICM and Martti Ahtisaari. On the other hand, due to the political situation in Indonesia especially in Aceh, it was convenient to develop the peace talks in a foreign country so they could be developed calmly and away from pressure.

- Loss of influence of the military. The army for 30 years was in charge of fighting against the separatist movement in Aceh. Its selfproclamation as a defender of the essence of Indonesia and therefore the 
unity of the country made it an obstacle to the pacification of the conflict. Its various military operations in Aceh only produced death, destruction and resentment. Its loss of power with the advent of democracy in Indonesia and especially its permanent control by Susilo Bambang Yudhoyono was the elimination of one of the main obstacles to negotiating.

- The destruction caused by the tsunami. The pain and death caused by the tsunami on December 26, 2005 produced, on the contrary, three positive effects for the course of the conflict. First, it made the society of Aceh engrossed in 30 years of armed conflict to pressure both the central government and the Free Aceh Movement for a negotiated peace. Furthermore, the Indonesian society pushed for an end to hostilities in the area. Secondly, the difficulties of maintaining the armed struggle with the presence of many international NGOs and global media as well as the levels of destruction that occurred stopped the violence. Thirdly, the economic destruction of Aceh was a stranglehold on the finances of the Gerakan Aceh Merdeka and on the resources of the Indonesian army and forced them to change strategy and to reduce their claims. 


\section{REFERENCES}

- Aspinall, Edward and Crouch, Harold «The Aceh peace process: why it failed» at http://www.eastwestcenter.org/fileadmin/stored/pdfs/PS oo1.pdf

- Azra, Azyumardi, «Pluralism, co-existence and religious harmony» at http://azyumardiazra.com/index.php?option=com_docman\&task=cat _view\&gid $=20 \&$ dir $=$ DESC\&order $=$ date\&limit $=10 \&$ limitstart $=0$

- Effendy, Bathiar (2003). «Explaining the uneasy relationship political antagonism between Islam and the State in Indonesia» in Islam and the State in Indonesia, New York, Ohio University Press

- GAM «What is the Free Aceh Movement?» at ttp://insideindonesia.org/ digest/dig89.htm

- Gelar, Andini and Mostaron, Tuty «Post election Aceh: an Outlook for peace and security» at http://www.rsis.edu.sg/publications/ Perspective/RSISo732009.pdf

- Griffiths, Martin «Giving peace a chance to take root in Aceh» at http:// www.hdcentre.org/files/Giving\%20peace\%20a\%20chance\%20 Aceh\%2028\%20Feb\%2003_o.pdf

- Gus Dur at http://www.tokohindonesia.com/ensiklopedi/a/abdurrah man-wahid/index.shtml

- Hajramurni, Andi «Kalla ready to play role as peace broker» at http:// www.thejakartapost.com/news/2009/09/28/kalla-ready-play-rolepeace-broker.html

- Henry Dunant Center at http://www.hdcentre.org/projects/acehindonesia

- ISIS «The East Timor crisis» at http://www.iiss.org/publications/ strategic-comments/past-issues/volume-5---1999/volume-5---issue-8/ the-east-timor-crisis/

- Hooker, Mb and Lindsey,Tim (2003). «Public faces of Sharia» in Studia Islamika vol $10, n^{0_{1}}$ 
- Hosen, Nadirsyah (2007). «Conclusion» in Sharia and Constitutional reform in Indonesia, Singapur, Iseas

- International Crisis Group «Recycling Militants in Indonesia: Darul Islam and the Australian Embassy Bombing» at http://www. crisisgroup.org/home/index.cfm?id=3280\&l=1

- Kingsbury, Damien «Peace Processes in Aceh and Sri Lanka: A Comparative Assessment « at http://www.securitychallenges.org.au/ ArticlePDFs/vol3no2Kingsbury.pdf

- Ley de descentralización regional «Menjada pemilu jurdil». at http:// ndijurdil.ndi.org/Law_32_2004_RegionalGovernance_EnglishVersion. pdf

- Linga, Abhoud Syed M. «Aceh peace process: A Lessons for Mindanao« at http://library.upmin.edu.ph/philmin/bangsamoro/IBS\%20Occasio nal\%20Paper\%202007-03\%20-\%20Lingga.pdf

- Llamazares, Dionisio (1989). «Modelo de utilidad» in Derecho eclesiástico del Estado: derecho de la libertad de conciencia, Universidad Complutense de Madrid, Madrid

- May, Bernhard «Law on the governing of Aceh» at http://www. conflictrecovery.org/bin/May-governing_aceh.ppt

- MoU «Memorandum of Understanding Between the Government of the Republic of Indonesia and the Free Aceh Movement» at http://www. cmi.fi/files/Aceh_MoU.pdf

- Pancasila «Pidato Soekarno: Lahirnya Pancasila» at http://kepusta kaan-presiden.pnri.go.id/speeches_clipping/index.

asp?box=detail\&from_box=list_245\&id=39\&page=8\&presiden=\&sear ch_presiden=\&search_tag=\&search_keyword=\&subjek=\&author=\&ac tivation_status=

- Ramage, Douglas, "Origins of discourse: politics and ideology since 1945» in Democracy, Islam and the ideology of tolerance, UK, Routledge, 1997, 10-44

- Rasyid, Ryaas (2003) «Regional autonomy and local politics in Indonesia» in Aspinall, Edward, Local power and politics in Indonesia. Decentralization\&Democratizacion, Iseas, Singapur 
- Tempo Interaktif «Operasi Militer di Aceh» at http://www. tempointeraktif.com/hg/timeline/2004/07/12/tml,20040712-01,id.html

- Tjhin, Christine Susana «Post Tsunami Reconstruction and Peace Building in Aceh:

- Political Impacts and Potential Risks« at http://www.csis.or.id/ working_paper_file/59/wpso53.pdf

- Simanjuntak, Hotli «New Aceh council to rethink controversial stoning bylaw» at http://www.thejakartapost.com/news/2009/10/23/newaceh-council-rethink-controversial-stoning-bylaw.html

- Soetjipto, Tomi «Aceh's Mecca pilgrims find homes washed away» at http://www.theage.com.au/news/asia-tsunami/acehs-mecca-pilgrimsfind-homes-washed-away/2005/01/28/1106850105912.html

- Solana, Javier «EU High Representative for the CFSP,welcomes the signature of the Memorandum of Understanding between the Government of Indonesia and the Free Aceh Movement» at http:// www.consilium.europa.eu/ueDocs/cms_Data/docs/pressData/en/ declarations/85995.pdf

- Sukma, Rizal «Security Operations in Aceh: Goals, Consequences, and Lessons» at http://www.eastwestcenter.org/fileadmin/stored/pdfs/ PSo03.pdf

- Willianson, Lucy «Aceh votes for major change» at http://news.bbc. co.uk/2/hi/asia-pacific/6171265.stm

- Yusuf, Irwandi «Elections must be peaceful in Aceh» at http://www. thejakartapost.com/news/2009/02/21/elections-must-be-peacefulaceh.html 


\section{ICIP WORKING PAPERS - SUBMISION GUIDELINES}

1. International Catalan Institution for Peace (ICIP):

The principle purpose of the ICIP is to promote a culture of peace in Catalonia as well as throughout the world, to endorse peaceful solutions and conflict resolutions and to endow Catalonia with an active role as an agent of peace and peace research.

2. Objectives of the Publication:

The ICIP wants to create an open forum on topics related to peace, conflict and security. It aims to open up debate and discussion on both theoretical and contemporary issues associated with the pursuit and maintenance of peace in our world. It strives to connect an eclectic group of voices including career academics, PhD students, NGO representatives, institutional representatives, and field workers and field writers to celebrate groundbreaking and constructive approaches to peace and conflict resolution.

3. Scope of the Publication (List of Themes):

The ICIP is interested in works related to peace, conflict and security research. It aims to provide an innovative and pluralist insight on topics of methodology of peace research, the history and development of peace research, peace education, peace-keeping and peace-creating, conflict resolution, human security, human rights, global security, environmental security, development studies related to peace and security, international law related to peace, democracy, justice and equality, disarmament, gender, identity and ethics related to peace, science and technology associated with peace and security. 


\section{Audience:}

The ICP aims to provide accessible, valuable and well-researched material for all those interested in the promotion of peace. Our audience includes fellow academics and researchers, student of peace and security, field workers, institutional and governmental representatives as well as the general public.

5. The review process:

ICIP WP is a peer reviewed publication. Submissions should be sent directly to the series editor (recerca.icip@gencat.cat), who will check whether the paper meets the formal and general criteria for a working paper and will commission a review.

6. Who may submit working papers:

a. The main criterion for the submission of Working Papers is whether this text could be submitted to a good academic journal.

b. ICIP staff and other fellows and visitors affiliated with the ICIP are expected to submit a working paper related to their research while at the ICIP.

7. Submission System:

All submissions can be made to the ICIP, e-mail address recerca.icip@ gencat.cat with "Working Papers - submission" in the subject line.

For a complete version of the ICIP WP submission guidelines, please visit the publications section of the website $w w w$.icip.cat.

Una versió completa i en català d'aquests criteris de sumbissió de texts la trobareu a la secció de publicacions del lloc web www.icip.cat.

Una versión completa y en castellano de estos criterios de sumisión de textos se encuentra en el apartado de publicaciones de la página web $w w w$. icip.cat. 


\section{NEXTS NUMBERS OF THE ICIP WORKING PAPERS SERIES}

Working Paper 2010/1: Territorial Autonomy and Self-Determination Conflicts. Opportunity and willingness. cases from Bolivia, Niger and Thailand, por Roger Suso.

\section{EDITED NUMBERS OF THE ICIP WORKING PAPERS SERIES}

Working Paper 2oo9/8: Indigenous People's Mobilization and their Struggle for Rights in Colombia, por Farid Samir Benavides.

Working Paper 2009/7: A Critical Application of Securitization Theory: Overcoming the Normative Dilemma of Writing Security, por Catherine Charrett.

Working Paper 2009/6: Bringing actors and violent conflict into forced migration literature. A model of the decision to return, por Inmaculada Serrano.

Working Paper 2009/5: The Quest for Regulating the Global Diamond Trade, por Franziska Bieri.

Working Paper 2009/4: Hezbollah's identities and their relevance for cultural and religious IR, por Pol Morillas Bassedas.

Working Paper 2oo9/3: Eleccions pacífiques a Costa d'Ivori a finals del 20o9? Avenços i obstacles de la construcció de pau al país ivorià, por Albert Caramés.

Working Paper 2009/2: Prohibició de submissió a nou judici - regla del ne bis in idem - en el sistema interamericà de drets humans i en el dret comparat, por Priscila Akemi Beltrame.

Working Paper 2009/1: Conflict prevention and descentralized governance, por Rafael Grasa y Arnau Gutiérrez Camps. 

